\title{
Analisis Video Comments to Video Views Ratio Tiktok Pada 10 Boyband Korea Paling Populer Sepanjang Tahun 2020
}

\author{
Alfonsia Mayestik Nggula Soro \\ Alvonsyasoro2001@gmail.com
}

\begin{abstract}
There are many social media platforms that can be used, one of the media that is being discussed is TikTok. This application itself was founded in September 2016 by ByteDance Company based in Beijing, China. In August 2018 TikTok merged with Musical.ly and that's when TikTok became the most downloaded app store. This study uses a quantitative exploratory method, and will calculate the ratios that exist on TikTok. This research only focuses on learning to use Video Comments to Video Views Ratio on the 10 Most Popular Korean Boybands in 2020. The purpose of this research is to determine the performance of the TikTok account of the 10 Most Popular Korean Boybands in 2020 Video Comments to Video Views Ratio. In this study, the Ateez Boyband had a better performance than the other Boybands.
\end{abstract}

\begin{abstract}
ABSTRAK
Terdapat banyak platform media sosial yang dapat digunakan, salah satu media yang sedang ramai diperbincangkan adalah TikTok. Aplikasi ini sendiri berdiri sejak September 2016 oleh ByteDance Company yang berbasis di Beijing, China. Pada bulan Agustus 2018 TikTok bergabung dengan Musical.ly dan di masa itulah TikTok sebagai the most downloaded app store. Penelitian ini menggunakan metode eksploratif kuantitatif, dan akan menghitung menggunakan rasio-rasio yang ada pada TikTok. Penelitian ini hanya berfokus untuk menghitung kredibilitas Video Comments to Video Views Ratio pada 10 Boyband Korea Paling Populer Tahun 2020. Tujuan dari dilakukan penelitian ini adalah untuk mengetahui kredibilitas performa dari akun TikTok 10 Boyband Korea Paling Populer Pada Tahun 2020 menggunakan Video Comments to Video Views Ratio. Pada penelitian ini Boyband Ateez memiliki kredibilitas performa yang lebih baik dibandingkan dengan Boyband yang lainnya.
\end{abstract}

KEYWORD : Social Media TikTok; Video Comments to Video Views Ratio ; Boyband Korea Paling Populer ; Credibility Account TikTok ; E-marketing. 


\section{PENDAHULUAN}

Teori uses and gratification pertama kali di kenalkan oleh Herbert Blummer dan Elihu Katz, teori uses and gratification (kegunaan dan kepuasan) adalah teori yang mengatakan bahwa pengguna media memiliki peran aktif dalam memilih dan menggunakan media tersebut untuk memenuhi kebutuhannya. Dalam Uses and Gratification, khalayak dianggap memiliki kecenderungan untuk memilih media sebagai alat untuk memenuhi kebutuhannya dan mengabaikan media yang dianggap tidak dapat memenuhi kebutuhannya. Masyarakat menggunakan media untuk memenuhi kebutuhan, ada yang memenuhi akan pengetahuan, informasi berita, informasi entertainment, dan juga hiburan (Andrian et al., 2021).

Terdapat banyak platform media sosial yang dapat digunakan, salah satu media yang sedang ramai diperbincangkan adalah TikTok. Aplikasi ini sendiri berdiri sejak September 2016 oleh ByteDance Company yang berbasis di Beijing, China. Pada bulan Agustus 2018 TikTok bergabung dengan Musical.ly dan di masa itulah TikTok sebagai the most downloaded app store (Umiyati, 2021). TikTok memungkinkan penggunanya membuat video yang awalnya berdurasi 15 detik sekarang menjadi 3 menit yang disertai dengan musik, filter, dan lain-lain. Tiktok sebagai aplikasi platform penyedia pembuatan konten baik berupa foto maupun video menarik yang tersebar di seluruh media sosial dan negara, salah satunya Indonesia (Ferniansyah et al., 2021).

Dalam perkembangan teknologi saat ini yang didukung oleh Internet, semua bidang telah mengalami kemajuan yang pesat terutama dalam bidang bisnis. Perusahaan yang dapat bersaing dalam suatu persaingan adalah perusahaan yang dapat menerapkan teknologi di perusahaannya. Dalam rangka meningkatkan persaingan usaha dan penjualan produk, salah satu metode implementasi teknisnya adalah dengan memasarkan berbagai produk atau jasa melalui penggunaan e-commerce atau perdagangan elektronik. (Khoziyah \& Lubis, 2021). Salah satu contohnya yaitu perusahaan-perusahaan dari 10 Boyband Korea yang Paling Populer Pada Tahun 2020. 10 Boyband tersebut diantaranya yaitu : Bangtan Sonyeondan (BTS), SuperM, NCT, Seventeen, Stray Kids, Monsta X,TXT, Ateez, GOT7, dan Cravity ("11 Boyband Korea Paling Populer Sepanjang Tahun 2020IDN TIMES"). Perusahaan-perusahaan tersebut telah memanfaatkan salah satu Teknik dalam digital marketing yang memainkan peran penting untuk menarik minat customer.

Penelitian ini menggunakan metode eksploratif kuantitatif, dan akan menghitung menggunakan rasio-rasio yang ada pada TikTok. Pada penelitian (I Putu Hendika Permana \& Ni Putu Suci Meinarni, 2021) menjelaskan bahwa terdapat 17 data yang relefan untuk di formulasikan menjadi rasio pada sosial media TikTok. Penelitian ini hanya berfokus untuk menghitung kredibilitas Video Comments to Video Views Ratio pada 10 Boyband Korea Paling Populer Tahun 2020. Adapun 10 Boyband Korea Paling Populer Pada Tahun 2020 yaitu : Bangtan Sonyeondan (BTS), SuperM, NCT, Seventeen, Stray Kids, Monsta X, TXT, Ateez, GOT7, dan Cravity ("11 Boyband Korea Paling Populer Sepanjang Tahun 2020 - IDN TIMES”). Tujuan dari dilakukan penelitian ini adalah untuk mengetahui kredibilitas performa dari akun TikTok 10 Boyband Korea Paling Populer Pada Tahun 2020 menggunakan Video Comments to Video Views Ratio. 


\section{TINJAUAN PUSTAKA}

Berada pada era postmodernisme yang memiliki berbagai perubahan terutama dalam kehidupan masyarakat yang mempengaruhi dunia industri, seperti halnya terjadi peningkatan dalam pelayanan di bidang ekonomi dengan peran media massa disini terlihat sangat kuat, dan merubah pola konsumsi masyarakat (Viona et al., 2021). Media sosial memberikan pengaruh yang cukup besar, saat ini media sosial dijadikan sarana berkomunikasi antara penjual dengan pembeli, selain itu media sosial memiliki potensi untuk menemukan konsumen serta membangun image tentang merk suatu produk (Nidaul Khasanah et al., 2020).

Dengan banyaknya aplikasi-aplikasi atau platform media sosial, TikTok menjadi salah satu aplikasi yang sekarang banyak digunakan dari berbagai kalangan artis, pejabat, pelaku usaha kecil, pebisnis, dan masyarakat umum lainnya. Vidio pendek merupakan hal yang sangat diminati di dunia internet, dimana video pendek yang dibuat tersebut bisa tersebar dalam waku 5 menit ke seluruh dunia (Wibowo \& Yudi, 2021). Aplikasi TikTok terdapat banyak video atau konten-konten yang menghibur seperti video parodi, dance, memasak, tutorial dan lain-lain. Tidak hanya itu, TikTok juga menjadi salah satu platform yang di gunakan sebagai media promosi yang dapat memberikan keuntungan bagi perusahaan, salah satu contohnya bagi perusahaan dan agensi yang menaungi artis-artis korea selatan.

Menurut penelitian yang dilakukan Wulandari (2018) seorang penggemar Kpop sering membeli barang-barang yang berhubungan dengan idolanya seperti album, baju, poster, merchandise, vote, tiket konser, bahkan tidak jarang ada yang rela hingga memesan ke Korea Selatan. Keberadaan penyanyi Kpop memengaruhi preferensi generasi milenial dalam banyak hal. Misalnya, meningkatnya penggunaan produk perawatan kulit dan produk makeup Korea, gaya Korea, konsumsi makanan Korea, dan lain-lain. Hal ini dilakukan sebagai bukti kecintaan penggemar ke idolanya.

Beberapa agensi seperti SM Entertainment hingga Big Hit Entertainment dalam situasi pandemi Covid-19 ini menyelenggarakan konser online sebagai pengganti konser offline. Hal ini tidak mematahkan semangat seorang k-popers untuk menonton. Mereka rela membayar tiket konser yang mahal hanya untuk melihat idola dari layar gawai. Tercatat lebih dari 750 ribu orang dari seluruh dunia menonton salah satu konser online dari grup BTS yang berkolaborasi dengan Lotte Duty Free dimana acara tersebut di siarkan melalui aplikasi TikTok (Sholikhah et al., 2021). Hal tersebut membuktikan bahwa pengaruh promosi dan pemanfaatan media sosial Tiktok yang di lakukan membawa dampak produksi dan keuntungan yang besar bagi perusahaaan atau agensi yang menaungi artisartis korea selatan tersebut.

TikTok dirasakan memiliki kekuatan ataupun pengaruh dalam industri, sehingga menimbulkan kualitas akun yang menentukan strata maupun kredibilitas pemilik akun. Kredibilitas akun TikTok merupakan suatu hal yang cukup penting untuk berbagai kepentingan. Kredibilitas sebuah akun TikTok dapat diukur dari tingkat performa yang dihasilkan secara matematis. Dalam mengukur performa diperlukan skala pengukuran yang tertuang ke dalam rasio (Putu \& Ariyanti, n.d.) 


\section{METODE PENELITIAN}

Penelitian ini menggunakan metode eksploratif kuantitatif untuk mengetahui kredibilitas dari performa akun TikTok 10 Boyband Korea paling populer sepanjang tahun 2020. Penelitian eksploratif adalah penelitian yang berupaya memaparkan atau menggambarkan fenomena dimana peneliti belum memiliki arah atau peta penjelasan tentang fenomena yang dihadapinya. Eksploratif adalah semacam pengumpulan data untuk menjawab persoalan yang menjadi minat peneliti (Mudjiyanto, 2018). Pada umumnya, tujuan dari penelitian eksploratif adalah untuk mendapatkan data dasar, yang diperlukan sebagai dasar penelitian lebih lanjut, atau dasar membuat suatu keputusan (Aryanti, 2016).

Tujuan dari penelitian ini yaitu mengetahui nilai kredibillitas dari performa akun TikTok 10 Boyband Korea paling populer sepanjang tahun 2020. Ada beberapa langkah yang harus dilakukan dalam penelitian ini, sehingga mampu menemukan peringkat pertama dari akun TikTok Boyband Korea paling populer yang memiliki performa terbaik.

Langkah-langkah yang dilakukan pada penelitian ini, diantaranya yaitu :

\section{Melakukan Eksplorasi Pada Website Untuk Menentukan Objek yang Akan Dianalisa.}

Eksplorasi ini dilakukan pada beberapa halaman website yang menyediakan informasi mengenai objek yang akan di teliti. Setelah eksplorasi selesai dilakukan, sehingga ditemukan nama-nama Boyband Korea yang akan dijadikan objek analisa. Setelah melakukan eksplorasi pada halaman website, maka langkah selanjutnya yaitu mencari nama akun TikTok dari masing-masing Boyband tersebut. Pastikan masingmasing Boyband tersebut memiliki akun TikTok.

\section{Menghitung Nilai Rata-Rata Variable Dari 10 Boyband Korea Paling Populer Sepanjang Tahun 2020.}

Pada langkah ini, peneliti menghitung nilai variable video comments dan variable video views. Untuk menghitung nilai rata-rata dari variabel video comments dan variabel video views yaitu dengan cara mengambil minimal 10 postingan kemudian di hitung sehingga menemukan nilai rata-rata dari masing-masing variabel. 


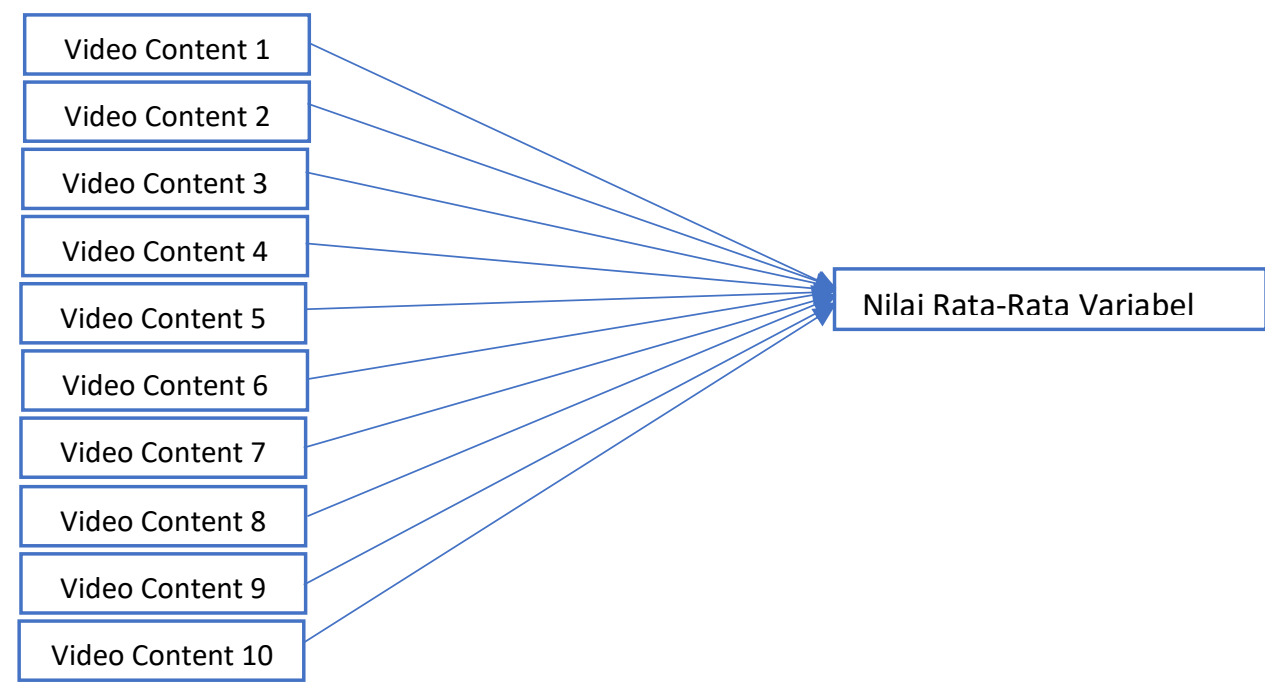

Gambar Analisa Nilai Rata-Rata Variabel

\section{Menghitung Nilai Kredibilitas Rasio}

Untuk menghitung nilai kredibilitas dari video comments to video views ratio, penelitii menggunakan cara membagi nilai variabel pertama dengan nilai variabel kedua. Jika video comments memiliki nilai 2000 dan video views memiliki nilai 3000, maka cara menghitungnya yaitu $2000: 3000=0,6$. Dengan begitu nilai dari video comments to video views ratio adalah 0,6 .

\section{Menentukan Peringkat Pada Akun TikTok}

Pada langkah terakhir yang dilakukan pada penelitian ini yaitu menentukan peringkat pada masing-masing rasio yang ada. Pada penentuan peringkat perlu melihat karakteristik dari rasio yang di teliti. Jika karakteristik rasio merupakan rendah, maka objek yang memiliki nilai terendah akan mendapatkan angka 10 dan objek yang memiliki nilai tertinggi akan mendapatkan angka 1. Namun jika rasio memiliki karakteritik tinggi maka objek yang mendapatkan nilai tinggi akan mendapatkan angka 10 dan objek yang mendapatkan nilai terendah akan mendapatkan angka 1. Setelah mendapatkan hasil kredibilitas ratio maka dapat disimpulkan objek yang mana mendapatkan peringkat 1 sampai dengan peringkat 10 . 


\section{HASIL DAN PEMBAHASAN}

Akun TikTok dari 10 Boyband Korea Paling populer Sepanjang Tahun 2020, diantaranya:

1. Bangtan Sonyeondan (BTS)

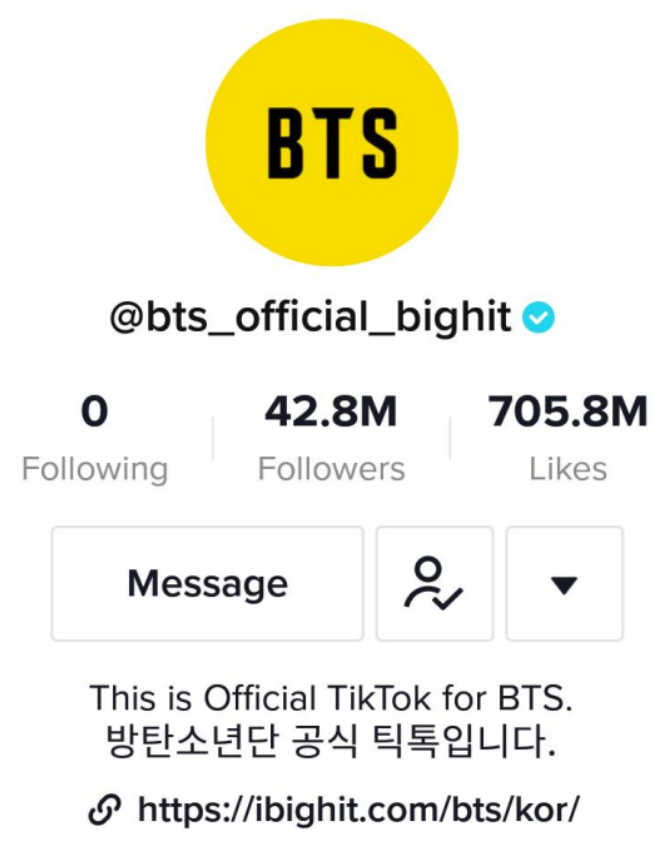

Gambar 1. Akun TikTok Bangtan Sonyeondan

Sumber : https://vt.tiktok.com/ZSeFV5dFD/ @ bts_official_bighit (akses pada 21-10-2021)

\section{SuperM}

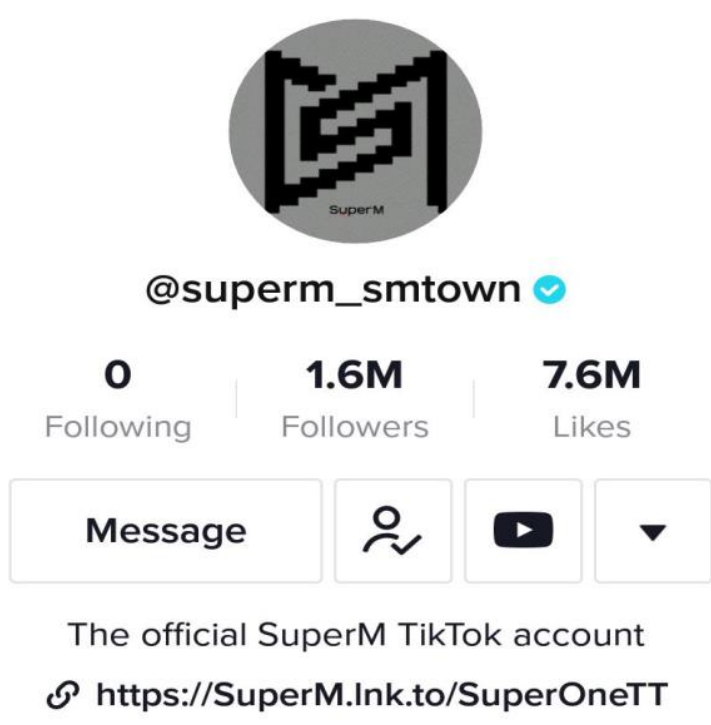

Gambar 2. Akun TikTok SuperM

Sumber : https://vt.tiktok.com/ZSeFVjbvX/ @superm_smtown (akses pada 21-10-2021) 


\section{NCT}

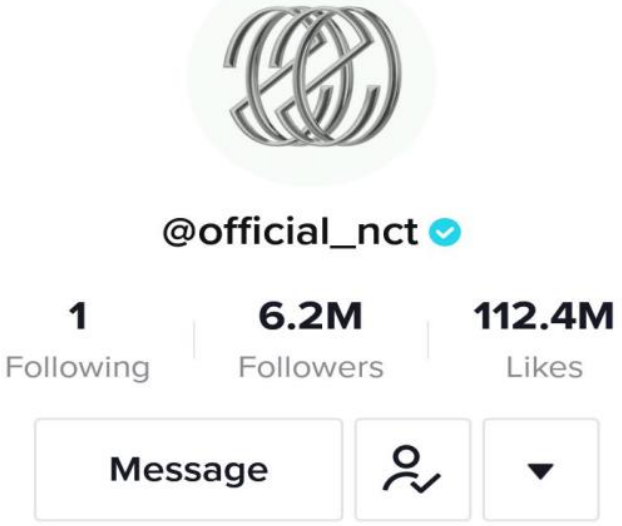

Gambar 3. Akun TikTok NCT

Sumber : https://vt.tiktok.com/ZSeFVfUmt/ @official_nct (akses pada 21-10-2021)

\section{Seventeen}

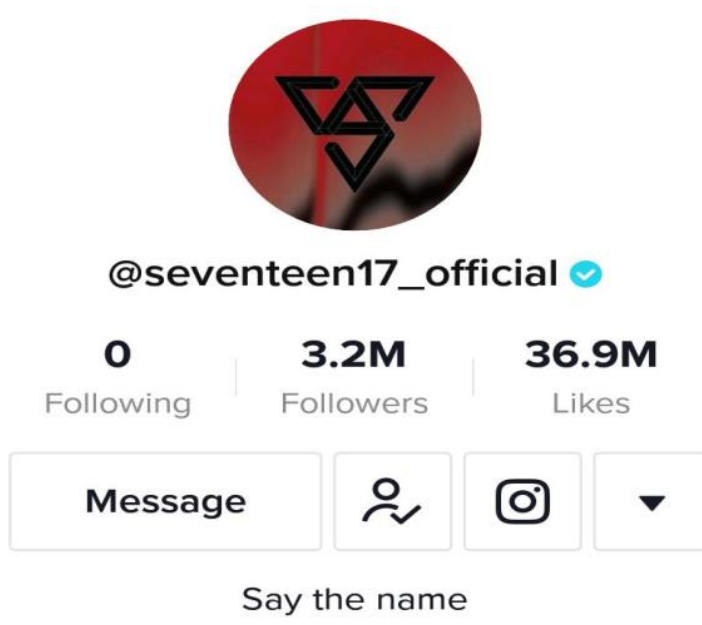

Gambar 4. Akun TikTok Seventeen

Sumber : https://vt.tiktok.com/ZSeFVuf36/ @ seventeen17_official (akses pada 21-10-2021) 


\section{Stray Kids}

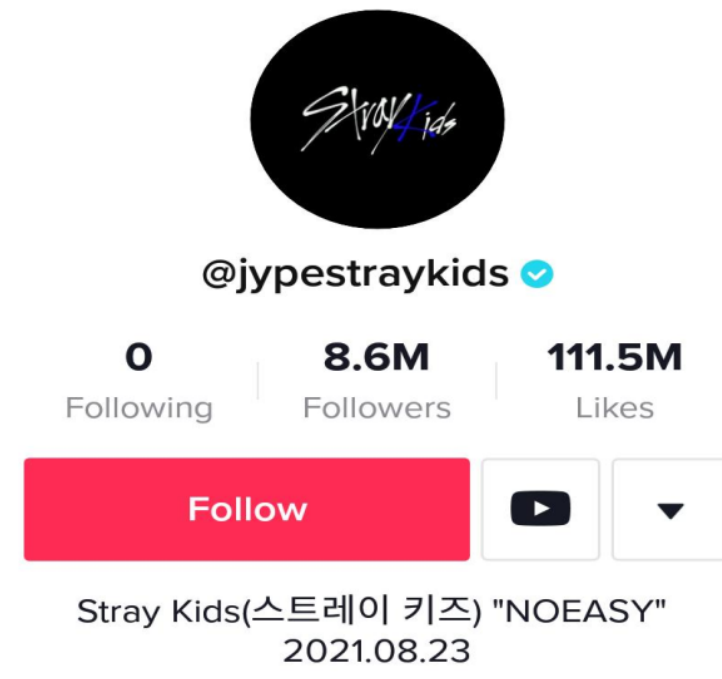

Gambar 5. Akun TikTok Stray Kids

Sumber : https://vt.tiktok.com/ZSeFVU7xD/ @jypestraykids (akses pada 21-10-2021)

\section{Monsta X}

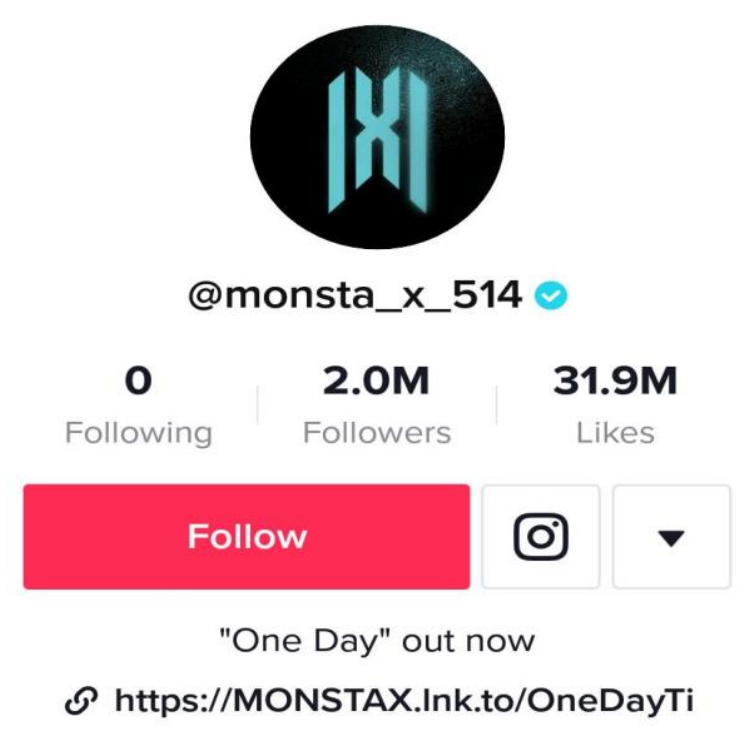

Gambar 6. Akun TikTok Monsta X

Sumber : https://vt.tiktok.com/ZSeFV6Bf9/ @ monsta_x_541 (akses pada 21-10-2021) 


\section{Tomorrow X Together}

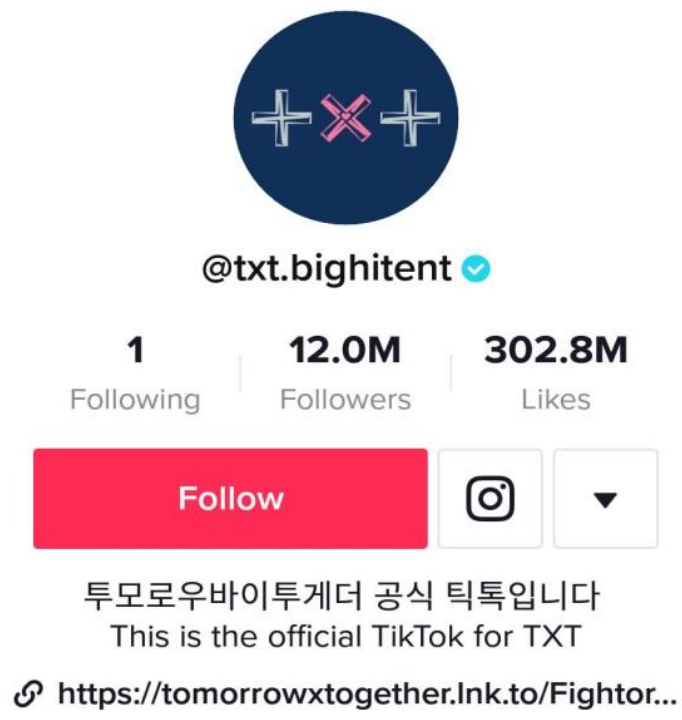

Gambar 7. Akun TikTok TXT

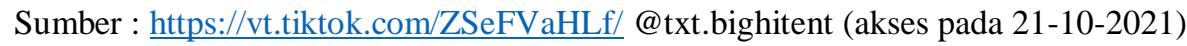

\section{Ateez}

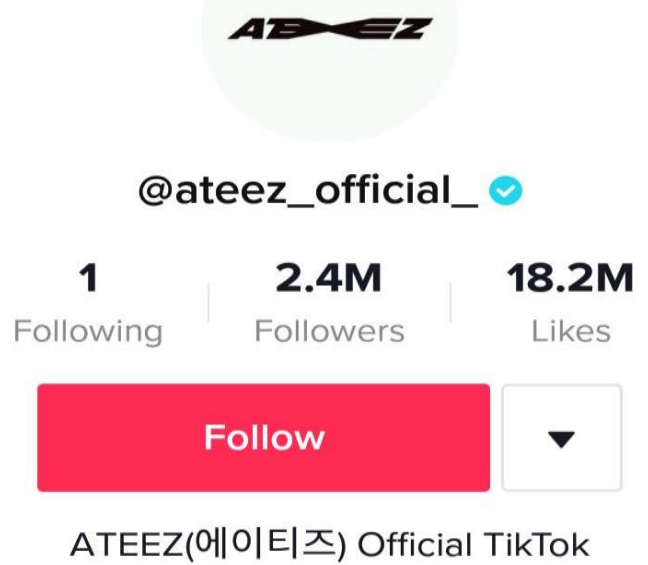

Gambar 8. Akun TikTok Ateez

Sumber : https://vt.tiktok.com/ZSeFVu1fv/ @ateez_official_(akses pada 21-10-2021) 


\section{GOT7}

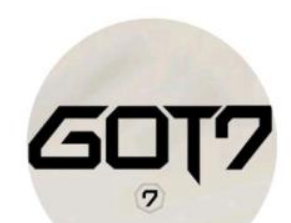

@got7official

\begin{tabular}{|c|c|c|}
\hline 0 & $2.6 \mathrm{M}$ & $10.1 \mathrm{M}$ \\
\hline Following & Followers & Likes \\
\hline Message & $\stackrel{0}{2}$ & $\nabla$ \\
\hline
\end{tabular}

Gambar 9. Akun TikTok GOT7

Sumber : https://vt.tiktok.com/ZSeFVjQEK/ @got7official (akses pada 21-10-2021)

\section{Cravity}

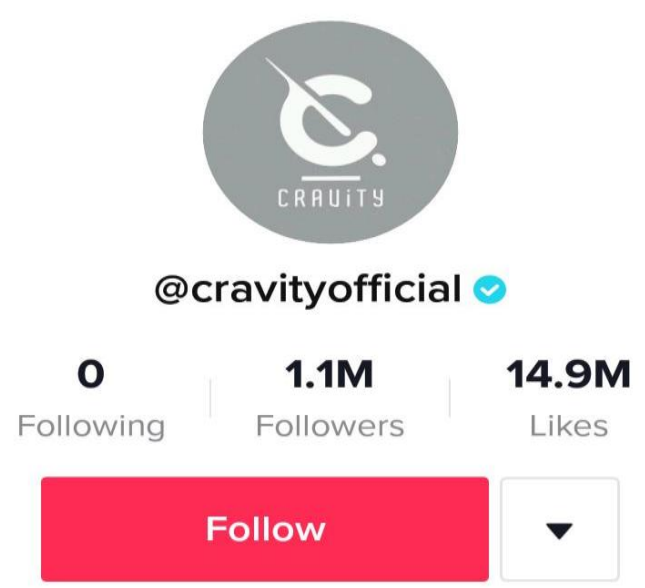

CRAVITY OFFICIAL TIKTOK

Gambar 10. Akun TikTok Cravity

Sumber : https://vt.tiktok.com/ZSeFVUneN/ @ cravityofficial (akses pada 21-10-2021) 
Dari kesepuluh akun Tiktok Boyband Korea Paling Populer Sepanjang Tahun 2020, Peneliti menemukan nilai dari masing-masing variabel yang ada untuk menghitung rasio Video Comments to Video Views dari setiap akun. Pada akun TikTok terdapat 7 Variabel, diantaranya yaitu :

1. Variabel Likes

2. Variabel Followers

3. Variabel Following

4. Variabel Video Likes

5. Variabel Video Comments

6. Vriabel Video Share

7. Variabel Video Views

Ketujuh Variabel tersebut yang akan melalui proses analisis antar variable dan diuji relevansi, sehingga dapat menjadi sebuah rasio yang relevan. Pada kesempatan ini, peneliti hanya fokus untuk menemukan hasil dari 2 variabel, yaitu:

1. Video Comments

2. Video Views

Dari kedua variable tersebut akan dianalisis sehingga menemukan nilai rata-rata dari variabel video comments dan variabel video views. Untuk menghitung nilai rata-rata dari variable video comments dan variable video views yaitu, dengan cara mengambil minimal 10 postingan kemudian di hitung sehingga menemukan nilai rata-rata dari masing-masing variable.

Berikut merupakan tabel rata-rata dari masing-masing boyband korea yang paling populer sepanjang tahun 2020, yaitu :

Tabel 1. Analisa Nilai Rata-Rata Nilai Variabel Video Comments dan Video Views Akun TikTok Bangtan Sonyeondan

\begin{tabular}{|c|r|r|}
\hline No & Video Comment & Video Views \\
\hline 1 & 196.000 & 21.800 .000 \\
\hline 2 & 349.300 & 52.200 .000 \\
\hline 3 & 300.200 & 29.500 .000 \\
\hline 4 & 281.200 & 29.600 .000 \\
\hline 5 & 394.600 & 49.200 .000 \\
\hline 6 & 174.700 & 26.300 .000 \\
\hline 7 & 432.500 & 62.200 .000 \\
\hline 8 & 347.900 & 55.500 .000 \\
\hline 9 & 307.300 & 82.700 .000 \\
\hline 10 & 200.700 & 52.200 .000 \\
\hline Total & $\mathbf{2 9 8 . 4 4 0}$ & $\mathbf{4 6 . 1 2 0 . 0 0 0}$ \\
\hline
\end{tabular}

Sumber : Pengolahan Data Excel 
Tabel 2. Analisa Nilai Rata-Rata Nilai Variabel Video Comments dan Video Views Akun TikTok SuperM

\begin{tabular}{|c|r|r|}
\hline No & Video Comment & Video Views \\
\hline 1 & 1.191 & 421.300 \\
\hline 2 & 2.094 & 382.600 \\
\hline 3 & 2.145 & 375.700 \\
\hline 4 & 3.461 & 477.200 \\
\hline 5 & 4.325 & 631.500 \\
\hline 6 & 4.394 & 625.400 \\
\hline 7 & 4.613 & 520.700 \\
\hline 8 & 3.187 & 1.000 .000 \\
\hline 9 & 1.308 & 667.900 \\
\hline 10 & 3.884 & 828.300 \\
\hline Total & $\mathbf{3 . 0 6 0}$ & $\mathbf{5 9 3 . 0 6 0}$ \\
\hline
\end{tabular}

Sumber : Pengolahan Data Excel

Tabel 3. Analisa Nilai Rata-Rata Nilai variable Video Comments dan Video Views Akun Tiktok NCT

\begin{tabular}{|c|r|r|}
\hline No & Video Comment & Video Views \\
\hline 1 & 12.100 & 1.600 .000 \\
\hline 2 & 28.800 & 6.400 .000 \\
\hline 3 & 13.300 & 2.600 .000 \\
\hline 4 & 23.000 & 2.700 .000 \\
\hline 5 & 30.300 & 3.400 .000 \\
\hline 6 & 24.400 & 3.500 .000 \\
\hline 7 & 11.800 & 2.200 .000 \\
\hline 8 & 7.099 & 1.900 .000 \\
\hline 9 & 30.200 & 2.400 .000 \\
\hline 10 & 19.800 & 3.100 .000 \\
\hline Total & $\mathbf{2 0 . 0 8 0}$ & $\mathbf{2 . 9 8 0 . 0 0 0}$ \\
\hline
\end{tabular}

Sumber : Pengolahan Data Excel 
Tabel 4. Analisis Nilai Rata-Rata Nilai Variabel Video Comments dan Video Views Akun Tiktok Seventeen

\begin{tabular}{|c|r|r|}
\hline No & Video Comment & Video Views \\
\hline 1 & 16.300 & 2.100 .000 \\
\hline 2 & 27.300 & 4.800 .000 \\
\hline 3 & 15.000 & 4.000 .000 \\
\hline 4 & 35.900 & 2.600 .000 \\
\hline 5 & 12.400 & 1.900 .000 \\
\hline 6 & 38.400 & 8.700 .000 \\
\hline 7 & 21.700 & 3.100 .000 \\
\hline 8 & 5.448 & 1.800 .000 \\
\hline 9 & 10.400 & 3.100 .000 \\
\hline 10 & 4.796 & 1.900 .000 \\
\hline Total & $\mathbf{1 8 . 7 6 4}$ & $\mathbf{3 . 4 0 0 . 0 0 0}$ \\
\hline
\end{tabular}

Sumber : Pengolahan Data Excel

Tabel 5. Analisis Nilai Rata-Rata Nilai Variabel Video Comments dan Video Views Akun Tiktok Stray Kids

\begin{tabular}{|c|r|r|}
\hline No & Video Comment & Video Views \\
\hline 1 & 44.500 & 6.800 .000 \\
\hline 2 & 39.000 & 6.100 .000 \\
\hline 3 & 2.581 & 1.400 .000 \\
\hline 4 & 16.900 & 4.600 .000 \\
\hline 5 & 10.300 & 3.700 .000 \\
\hline 6 & 13.800 & 5.300 .000 \\
\hline 7 & 12.700 & 4.000 .000 \\
\hline 8 & 40.000 & 7.300 .000 \\
\hline 9 & 22.200 & 6.000 .000 \\
\hline 10 & 54.600 & 5.100 .000 \\
\hline Total & $\mathbf{2 5 . 6 5 8}$ & $\mathbf{5 . 0 3 0 . 0 0 0}$ \\
\hline
\end{tabular}

Sumber : Pengolahan Data Excel 
Tabel 6. Analisis Nilai Rata-Rata Nilai Variabel Video Comments dan Video Views Akun TikTok Monsta X

\begin{tabular}{|c|r|r|}
\hline No & Video Comment & Video Views \\
\hline 1 & 2.169 & 337.300 \\
\hline 2 & 1.620 & 264.500 \\
\hline 3 & 1.616 & 274.200 \\
\hline 4 & 1.496 & 336.200 \\
\hline 5 & 304 & 183.700 \\
\hline 6 & 2.766 & 805.200 \\
\hline 7 & 15.100 & 3.100 .000 \\
\hline 8 & 1.492 & 257.500 \\
\hline 9 & 2.492 & 666.700 \\
\hline 10 & 1.724 & 441.800 \\
\hline Total & 3.078 & 666.710 \\
\hline
\end{tabular}

Sumber : Pengolahan Data Excel

Tabel 7. Analisis Nilai Rata-Rata Nilai Variabel Video Comments dan Video Views Akun TikTok Tomorrow X Together

\begin{tabular}{|c|r|r|}
\hline No & Video Comment & Video Views \\
\hline 1 & 34.000 & 9.200 .000 \\
\hline 2 & 16.100 & 3.300 .000 \\
\hline 3 & 22.400 & 2.800 .000 \\
\hline 4 & 19.100 & 3.400 .000 \\
\hline 5 & 24.700 & 3.500 .000 \\
\hline 6 & 19.400 & 2.600 .000 \\
\hline 7 & 13.800 & 2.600 .000 \\
\hline 8 & 24.000 & 4.000 .000 \\
\hline 9 & 18.800 & 3.300 .000 \\
\hline 10 & 5.223 & 1.900 .000 \\
\hline Total & 19.752 & 3.660 .000 \\
\hline
\end{tabular}

Sumber : Pengolahan Data Excel 
Tabel 8. Analisis Nilai Rata-Rata Nilai Variabel Video Comments dan Video Views Akun TikTok Ateez

\begin{tabular}{|c|r|r|}
\hline No & Video Comment & Video Views \\
\hline 1 & 1.435 & 106.200 \\
\hline 2 & 11.200 & 735.000 \\
\hline 3 & 4.035 & 448.000 \\
\hline 4 & 1.436 & 170.300 \\
\hline 5 & 1.369 & 217.400 \\
\hline 6 & 2.378 & 337.400 \\
\hline 7 & 2.405 & 334.400 \\
\hline 8 & 2.281 & 412.100 \\
\hline 9 & 1.383 & 294.800 \\
\hline 10 & 3.402 & 361.600 \\
\hline Total & $\mathbf{3 . 1 3 2}$ & $\mathbf{3 4 1 . 7 2 0}$ \\
\hline
\end{tabular}

Sumber : Pengolahan Data Excel

Tabel 9. Analisis Nilai Rata-Rata Nilai Variabel Video Comments dan Video Views Akun TikTok GOT7

\begin{tabular}{|c|r|r|}
\hline No & Video Comment & Video Views \\
\hline 1 & 10.600 & 2.300 .000 \\
\hline 2 & 5.595 & 2.500 .000 \\
\hline 3 & 3.420 & 2.000 .000 \\
\hline 4 & 9.198 & 10.200 .000 \\
\hline 5 & 7.267 & 2.400 .000 \\
\hline 6 & 4.518 & 4.400 .000 \\
\hline 7 & 5.139 & 3.700 .000 \\
\hline 8 & 5.704 & 2.000 .000 \\
\hline 9 & 4.644 & 2.300 .000 \\
\hline 10 & 7.221 & 4.700 .000 \\
\hline Total & $\mathbf{6 . 3 3 1}$ & $\mathbf{3 . 6 5 0 . 0 0 0}$ \\
\hline
\end{tabular}

Sumber : Pengolahan Data Excel 
Tabel 10. Analisis Nilai Rata-Rata Nilai Variabel Video Comments dan Video Views Akun TikTok Cravity

\begin{tabular}{|c|r|r|}
\hline No & Video Comment & Video Views \\
\hline 1 & 14.000 & 1.600 .000 \\
\hline 2 & 1.644 & 253.200 \\
\hline 3 & 751 & 149.500 \\
\hline 4 & 662 & 116.600 \\
\hline 5 & 2.932 & 279.800 \\
\hline 6 & 708 & 130.600 \\
\hline 7 & 953 & 186.100 \\
\hline 8 & 5.821 & 340.500 \\
\hline 9 & 4.124 & 464.100 \\
\hline 10 & 2.929 & 363.000 \\
\hline Total & 3.452 & 388.340 \\
\hline
\end{tabular}

Sumber : Pengolahan Data Excel

Setelah Menghitung nilai rata-rata tersebut, maka akan menemukan hasil akhir nilai rata-rata dari variabel video comments dan video views.

Tabel 11. Nilai Variabel Pada Akun TikTok 11 Boyband korea yang paling populer sepanjang tahun 2020

\begin{tabular}{|l|c|c|c|c|c|c|c|c|c|c|}
\hline \multicolumn{1}{|c|}{ Variable } & BTS & SuperM & NCT & Seventeen & Stray Kids & Monsta X & TXT & ATEEZ & GOT 7 & Cravity \\
\hline Video Comments & 298.440 & 3.060 & 20.080 & 18.764 & 25.658 & 3.078 & 19.752 & 3.132 & 6.331 & 3.452 \\
\hline Video Views & 46.120 .000 & 593.060 & 2.980 .000 & 3.400 .000 & 5.030 .000 & 666.710 & 3.660 .000 & 341.720 & 3.650 .000 & 388.340 \\
\hline
\end{tabular}

Sumber : Pengolahan Data Excel

Pada Akun TikTok terdapat 17 Rasio Yang relevan digunakan untuk mengukur kredibilitas pada masing-masing akun. Namun pada penelitian kali ini hanya berfokus untuk menghitung Video Comments to Views Ratio. Untuk menghitung kredibilitas dari masing-masing akun TikTok setiap boyband, peneliti menghitung dengan cara : Variabel 1 akan dibagi dengan variabel 2, sehingga ditemukan hasil analisa dari rasio tersebut.

Tabel 12. Hasil Perhitungan Rasio Akun TikTok

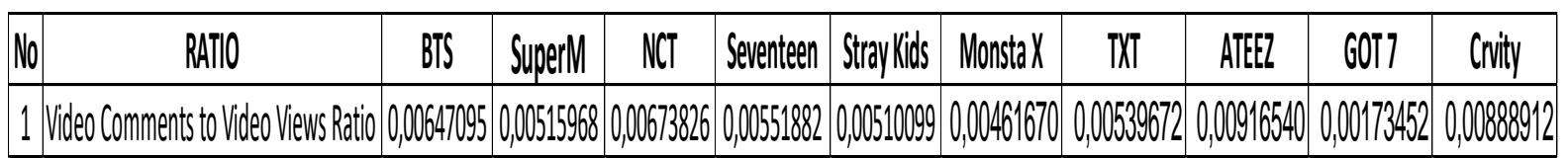


Video Comments to Video Views Ratio memiliki karakteristik yang tinggi, artinya semakin tinggi nilai yang dihasilkan maka semakin baik kredibilitas dari performa akun tersebut. Untuk memberikan peringkat pada masing-masing Boyband, peneliti memberikan angka 10 kepada Boyband yang mendapatkan nilai tertinggi dan angka 1 untuk Boyband yang mendapatkan nilai terendah.

Berikut merupakan tabel urutan nilai yang dihasikan oleh masing-masing Boyband :

Tabel 13. Nilai Rasio Akun TikTok Boyband Korea Paling Populer Sepanjang Tahun 2020

\begin{tabular}{|c|c|c|c|c|c|c|c|c|c|c|}
\hline Karakteristik & BTS & SuperM & NCT & Seventeen & Stray Kids & Monsta X & TXT & ATEEZ & GOT 7 & Cravity \\
\hline Tinggi & 7 & 4 & 8 & 6 & 3 & 2 & 5 & 10 & 1 & 9 \\
\hline
\end{tabular}

Sumber : Pengolahan Data Excel

Dari Tabel Nilai Rasio Akun TikTok Boygband Korea Paling Populer Sepanjang Tahun 2020 dapat disimpulkan bahwa Ateez mendapatkan nilai tertinggi untuk rasio Video Comments to Video Views. Sedangkan akun TikTok GOT7 mendapatkan nilai terendah untuk rasio ini. Jadi, Pada penelitian ini Boyband Ateez memiliki kredibilitas performa yang lebih baik dibandingkan dengan Boyband yang lainnya.

\section{KESIMPULAN}

Tujuan dari penelitian ini adalah mengetahui kredibilitas performa dari akun TikTok 10 Boyband Korea Paling Populer Sepanjang Tahun 2020 menggunakan Video Comments to Video Views Ratio. Boyband Korea Paling Populer Sepanjang Tahun 2020 tersebut diantaranya : BTS, SuperM, Nct, Seventeen, Stray Kids, Monsta X, Txt, Ateez, Got7, dan Cravity. Dari Kesepuluh Boyband tersebut dapat disimpulkan bahwa :

1. Peringkat pertama diraih oleh Boyband Ateez dengan nilai 0,00916540

2. Peringkat kedua diraih oleh Boyband Cravity dengan nilai 0,00888912

3. Peringkat ketiga diraih oleh Boyband NCT dengan nilai 0,00673826

4. Peringkat keempat diraih oleh Boyband BTS dengan nilai 0,00647095

5. Peringkat kelima diraih oleh Boyband Seventeen dengan nilai 0,00551882

6. Peringkat keeman diraih oleh Boyband TXT dengan nilai 0,00539672

7. Peringkat ketujuh diraih oleh Boyband SuperM dengan nilai 0,00515968

8. Peringkat kedelapan diraih oleh Boyband Stray Kids dengan nilai 0,00510099

9. Peringkat kesembilan diraih oleh Boyband Monsta X dengan nilai 0,00461670

10. Peringkat kesepuluh diraih oleh Boyband GOT7 dengan nilai 0,00173452 


\section{Daftar Pustaka}

Andrian, A. D., Luik, J. E., \& Tjahjo, J. D. W. (2021). Motif Masyarakat Indonesia Menggunakan Aplikasi Tiktok Selama Masa Pandemi Covid-19. Jurnal E-Komunikasi, $9(1)$.

Aryanti, Y. R. D. (2016). BAB III Pengetahuan Ibu Tentang Alat Permainan Edukatif dan Penggunaannya untuk Merangsang Perkembangan Anak Usia Pra-Sekolah. Semarang : Unika Soegijapranata., 1, 1-476. http://repository.unika.ac.id/13114/4/11.40.0002 Yosefa Rosselo Dwi Aryanti BAB III.pdf

Ferniansyah, A., Nursanti, S., \& Nayiroh, L. (2021). Pengaruh Media Sosial Tiktok terhadap Kreativitas Berpikir Generasi Z. Syntax Literate; Jurnal Ilmiah Indonesia, 6(9), 42874298.

I Putu Hendika Permana, \& Ni Putu Suci Meinarni. (2021). Ratio Analysis on Tiktok (Social Media) for Qualitative Research Using Explorative Methods. Jurnal Ekonomi \& Bisnis JAGADITHA, 8(1), 30-38. https://doi.org/10.22225/jj.8.1.2944.30-38

Khoziyah, S., \& Lubis, E. E. (2021). Pengaruh Digital Marketing Terhadap Keputusan Pembelian Followers Online Shop Instagram@ Kpopconnection. Jurnal Ilmu Komunikasi (JKMS), 10(1), 39-50.

Mudjiyanto, B. (2018). Tipe Penelitian Eksploratif Komunikasi. Jurnal Studi Komunikasi Dan Media, 22(1), 65. https://doi.org/10.31445/jskm.2018.220105

Nidaul Khasanah, F., Herlawati, Samsiana, S., Trias Handayanto, R., Setyowati Srie Gunarti, A., Irwan Raharja, Maimunah, \& Benrahman. (2020). Pemanfaatan Media Sosial dan Ecommerce Sebagai Media Pemasaran Dalam Mendukung Peluang Usaha Mandiri Pada Masa Pandemi Covid 19. Jurnal Sains Teknologi Dalam Pemberdayaan Masyarakat, 1(1), 51-62. https://doi.org/10.31599/jstpm.v1i1.255

Putu, N., \& Ariyanti, D. (n.d.). Analisis Video Comments to Video Views Ratio Tiktok Pada Top 5 Vendor Smartphone di Indonesia.

Sholikhah, Z., Psikologi, P. S., Psikologi, F., \& Surakarta, U. M. (2021). REMAJA PENGGEMAR K-POP DI KOTA SURAKARTA PENGGEMAR K-POP DI KOTA SURAKARTA.

Umiyati. (2021). No 主観的健康感を中心とした在宅高齢者における 健康関連指標に 関する共分散構造分析Title.4(1), 6.

Viona, V., Yohanes, K., Mega, L. S., Kurniawati, W., Farady Marta, R., \& Isnaini, D. M. (2021). Narasi Shopee Dalam Mengembangkan Ekonomi Kreatif Berbasis Teknologi ECommerce Di Era Modern. AGUNA: Jurnal Ilmu Komunikasi, I(2), 46-65. http://ejournal.amikompurwokerto.ac.id/index.php/AGUNA

Wibowo, T., \& Yudi. (2021). Studi Penetrasi Aplikasi Media Sosial Tik-Tok Sebagai Media 
Pemasaran Digital : Studi Kasus Kota Batam. Conference on Business, Social Sciences and Technology, 1(1), 662-669. https://journal.uib.ac.id/index.php/conescintech https://www.ejournal.warmadewa.ac.id/index.php/jagaditha/article/view/294 